\title{
Information and Communication Technology Profiles of College Students with Learning Disabilities and Adequate and Very Poor Readers
}

\author{
Catherine S. Fichten ${ }^{1,2,3,4}$, Mai N. Nguyen ${ }^{1}$, Laura King ${ }^{5}$, Maria Barile ${ }^{1}$, Alice Havel ${ }^{6}$, Zohra Mimouni ${ }^{7}$, \\ Alexandre Chauvin ${ }^{1,5,6}$, Jillian Budd ${ }^{1}$, Odette Raymond ${ }^{8}$, Jean-Charles Juhel ${ }^{9} \&$ Jennison Asuncion $^{1}$ \\ ${ }^{1}$ Adaptech Research Network, Montreal, Canada \\ 2 Department of Psychology, Dawson College, Montreal, Canada \\ ${ }^{3}$ Department of Psychiatry, Jewish General Hospital, Montreal, Canada \\ ${ }^{4}$ Department of Psychiatry, McGill University, Montreal, Canada \\ ${ }^{5}$ Langues: Trilinguisme et cultures, Cégep André-Laurendeau, LaSalle, Canada \\ ${ }^{6}$ Student AccessAbility Center, Dawson College, Montreal, Canada \\ ${ }^{7}$ Département des Langues Modernes et Traduction, Collège Montmorency, Laval, Canada \\ ${ }^{8}$ Services d'aide à l'intégration des élèves, Cégep du Vieux Montréal, Montreal, Canada \\ ${ }^{9}$ Services adaptés, Cégep de Sainte-Foy, Quebec, Canada \\ Correspondence: Catherine S. Fichten, Department of Psychology, Dawson College, 3040 Sherbrooke St. West, \\ Montreal, QC, H3Z 1A4, Canada. Tel: 1-514-931-8731 ext 1546. E-mail: catherine.fichten@mcgill.ca
}

Received: September 24, 2012

doi:10.5539/jel.v2n1p176
Accepted: November 5, 2012

Online Published: January 16, 2013

URL: http://dx.doi.org/10.5539/jel.v2n1p176

\begin{abstract}
We interviewed 58 experts (30 in French, 28 in English) about potentially useful information and communication technologies (ICTs) for Québec college students with a learning disability (LD) and evaluated whether college students with an LD $(\mathrm{n}=74)$, in fact, used these. We also compared ICT use, learning opportunities, and attitudes among three groups of students from Montreal area French and English language colleges: (1) students with an LD, and (2) students who, based on a reading comprehension test, were categorized as adequate readers (approximately top 50\%) or (3) very poor readers (approximately bottom 20\%). Results indicate important discrepancies between the views of the experts and the realities of students with LDs. Moreover, students with an LD use significantly fewer different types of ICTs than those without an LD.
\end{abstract}

Keywords: information and communication technologies, ICT, learning disability, college, university, post-secondary, experts, students, good and poor readers

\section{Introduction}

The highly-regarded Québec publication on learning disabilities, Rendez-vous AQETA, recently devoted an entire issue (2011, volume 25 , issue 2 ) to postsecondary education. This reflects the reality that learning disabilities (LDs) are the most common disabilities among Québec's junior/community college (Lavallée, Raymond, \& Savard, 2011) and university students (Gagné \& Tremblay, 2011). For example, in 2010, among students enrolled in compulsory mother tongue junior/community college classes, we found that $4.0 \%$ of students from English and 4.4\% from French language junior/community colleges in Quebec, a primarily French speaking province of Canada, self-reported a "learning disability such as dyslexia" (Fichten et al., in press).

\subsection{Definition of Learning Disabilities and Description}

The Learning Disabilities Association of Canada (undated) defines learning disabilities as,

"A number of disorders which may affect the acquisition, organization, retention, understanding or use of verbal or nonverbal information. These disorders affect learning in individuals who otherwise demonstrate at least average abilities essential for thinking and/or reasoning. As such, learning disabilities are distinct from global intellectual deficiency." 
Ranging in severity, learning disabilities may interfere with one or more of the following: reading, oral language, written language, and mathematics. Learning disabilities may also involve difficulties with organizational skills.

A specific type of learning disability (LD), known as dyslexia, is manifested in reading difficulties related to decoding problems and comprehension difficulties. This is the most common of the learning disabilities everywhere, including Québec (Mimouni \& King, 2007). Dyslexia is often comorbid with physical and sensory disabilities (Fichten et al., 2006) as well as with other forms of LD, such as problems with written language (e.g., spelling and written expression), oral language (e.g., listening, speaking, understanding), and mathematics (e.g., computation, problem solving) (Walcot-Gayda, 2004). The Learning Disabilities Association of Quebec (undated) notes that, "The most common decoding problems are:

- Auditory or phonetic confusion (spagetti/spadetti)

- Reversals (pacific/sapific)

- Omissions (gasoline/gasline)

- $\quad$ Additions (odor/order)

- $\quad$ Substitutions (dress/drest)

- Slow, hesitant, choppy, syllable-by-syllable reading

- Difficulty dividing words into syllables

- Lack of awareness of punctuation."

Individuals with dyslexia may grasp only part of the meaning of what they read. Many do not like reading and often avoid subjects or activities that require reading or writing. For example, a college student, when asked how she studies, told us, "Well, I buy two copies of the textbook. Then, while my father reads from his copy of the book aloud to me, I listen and follow along in my own copy of the book" (Author's files, 2006). Similarly, many students have difficulty with spelling and written expression. For example, one English speaking student, whose last name happens to be French, received the following comment from her professor on her term paper, "I understand that you Francophones have difficulty with spelling and sentence structure. But please, at least, refer to a dictionary" (Author's files, 1995). This particular student also managed to misspell her own name on another paper.

Although it is clear that problems with reading and writing can cause major academic difficulties, many students are unaware they have a learning disability, and experience problems only when they enter college or university where reading loads get heavy, where papers are expected to be written grammatically, and where simply listening to the professor in class is not adequate for academic success (Harrison, Nichols, \& Larochette, 2008; Harrison, Larochette, \& Nichols, 2007). In the past, the problem of under-recognition of learning disabilities has been especially common among Francophones, where parents, teachers, counsellors, psychologists, and students themselves were less familiar with the disorder (King, Mimouni, \& Courtemanche, 2006; Chouinard \& Déry, 2008). In fact, in Quebec students with learning disabilities are considered part of the "clientèle émergente" (emerging clientele). Of course, students with LDs in the English world "emerged" long ago. For example, the Journal of Learning Disabilities was founded in 1968.

\subsection{Information and Communication Technologies (ICTs)}

Although learning disabilities are potentially devastating for academic work, a variety of general use and specialized information and communication technologies (ICTs) are available to help enhance the academic success and satisfaction of students with learning disabilities, as shown by Hewlett, Burnett, and Owen's review (2006) and by Draffan, Evans, and Blenkhorn's (2007) data on 455 British postsecondary students with learning disabilities. Most of these ICTs are well known in the English language world, since they were developed in America or England. Moreover, these countries have legislation which compels schools to use them (Draffan et al., 2007; Brown, 2007), unlike the situation in Québec (AQICESH, 2011). Recently, French language resources have also provided annotated listings of these (e.g., Adaptech Research Network, 2012; Rousseau, 2010).

Therefore, one of our goals in the present investigation was to compare experts' views about potentially helpful ICTs and about ICTs that students with LDs actually use. A second goal was to compare ICT use and experiences of students with LDs to those of adequate readers and also to a group not typically mentioned in the literature, namely very poor readers who do not report an LD. Although both our own as well as others' studies have shown that these students exist in Canadian junior/community colleges and universities in large numbers (Fichten et al., in press; Parrila, Georgiou, \& Corkett, 2007; Mimouni, 2006; Mimouni \& King, 2007), little is known about their ICT use. 


\subsection{Present Investigation}

In the fall of 2009 we interviewed 58 experts (30 in French, 28 in English) about potentially useful ICTs for Québec college students with an LD (Fichten et al., 2012). In the spring 2011 semester, we evaluated whether college students with LDs, in fact, used these ICTs. We also compared ICT use and learning opportunities among students with and without an LD from English and French language colleges. Because a subsample of participants completed a reading comprehension test they could be classified as adequate or very poor readers. So we also examined attitudes among three groups of students: students with an LD and students without an LD who were classified as adequate readers (approximately top 50\%) or very poor readers (approximately bottom $20 \%$ ).

\section{Method}

\subsection{Participants}

The 196 participants, 74 of whom self-reported "a learning disability such as dyslexia" and 122 of whom did not, were enrolled in three Montreal area public junior/community colleges (1 English and 2 French). All indicated that they were most fluent in the language of instruction at their college and all had completed at least one semester of studies. Eighty-four percent of students with an LD indicated that they were registered to receive disability related services from their college. Most students were enrolled in social science programs. To avoid issues related to recent immigration from non-English or French speaking countries, we excluded students whose best language was not the language of instruction at their college. Gender and language data are available in Table 1.

Table 1. Sex, language and LD status of participants

\begin{tabular}{llcc}
\hline \multirow{2}{*}{ Group } & \multirow{2}{*}{ Language } & \multicolumn{2}{c}{ Gender } \\
\cline { 3 - 4 } & & Female & Male \\
\hline Non-LD & English & 32 & 30 \\
& French & 31 & 29 \\
LD & English & 25 & 8 \\
& French & 27 & 14 \\
\hline
\end{tabular}

Because many of these students were participating in a larger study (Fichten et al., in press), we have reading comprehension categories for a subsample of 96 participants without an LD: 53 scored as Adequate and 43 as Very Poor Readers. We excluded students who scored as "Poor Readers" because we wanted to examine ICT use among students whose reading comprehension was adequate as well among those who could, possibly, also benefit from specialized ICTs. Among students who self-reported an LD, approximately $1 / 3$ fell into the Adequate category, suggesting difficulties with academic tasks other than reading, such as writing or mathematics.

\subsection{Procedure}

Participants were selected using a "filtration" process. First, early in 2010 we administered a measure of reading experiences in elementary school (Fichten et al., in press; McGonnell, Parrila, \& Deacon, 2007; Parrila, Georgiou, \& Corkett, 2007) to 1889 students over the age of 18 who were enrolled in a compulsory mother tongue course and who had completed at least one semester at one metropolitan English college and two metropolitan French language colleges. In the fall of 2010 we invited all students to complete a reading comprehension test (Fichten et al., in press; Institut de Recherche et d'Évaluation Psychopédagogique (I.R.E.P.) Inc., 2000). We then invited all students who did so to complete a measure of ICT use in 2011.

Because we were especially interested in Very Poor Readers and in students with LD, we also sought students in these groups though the colleges' learning/tutoring centers, through their access centers for students with disabilities, as well as through programs known to attract relatively weak readers. Of course, we do not know the reading comprehension scores of many of these students.

All students completed an online ICT questionnaire in the spring of 2011. This included questions about demographics, academic program, attitudes toward ICTs, as well as the POSITIVES Scale (Postsecondary Information Technology Initiative Scale), a 26-item objective measure concerning how well students' ICT 
related needs are being met (Fichten et al., 2010; Nguyen, Fichten, \& Budd, in press).

\section{Results}

Males and females, whether they had an LD or not, did not differ on the number of ICTs used. Nor did students from two-year pre-university or three year career/technical programs.

\subsection{ICTs: Students With and Without an LD}

All students were presented with a list of 21 ICTs, partly based on the experts' recommendations in our previous investigation (Fichten et al., 2012). They were asked to indicate whether they used each ICT for school work. Results indicate that most students ( $84 \%$ of students with and $85 \%$ of those without an LD) use a Windows based computer. The Chi-Square test of independence shows that students from English colleges, whether they had an $\mathrm{LD}, \mathrm{X}^{2}(1,72)=8.94, \mathrm{p}=.003$, or not, $\mathrm{X}^{2}(1,121)=4.97, \mathrm{p}=.026$, were significantly more likely to use a Macintosh computer than students from the French colleges. It is noteworthy that $44 \%$ of students with an LD from the English college reported using a Macintosh, while only $26 \%$ of those without an LD did so. Comparable figures for French colleges were $13 \%$ and $10 \%$, respectively.

Comparison of the experts' ICT recommendations and ICTs used by students with LDs shows important gaps. Table 2 reveals that students with an LD do not use many of the ICTs that could, potentially, benefit them. Conversely, the experts did not mention some software tools that students did indicate using to do their school work, such as smartphones/cell phones/iPods, MP3 players, and instant messaging.

There were few significant differences in software used to do school work between French and English students with LDs: two ICTs were more extensively used in French colleges (Antidote [French language grammar/spelling software], WordQ) and four ICTs were more frequently used in the English college (smartphone/cell phone/iPod, instant messaging, Kurzweil, scanning and optical character recognition [OCR]). Among students without an LD, there were only 3 significant differences: one indicated more frequent use in French colleges (Antidote) while 2 showed more frequent use in the English college (smartphone/cell phone/iPod, and instant messaging).

Table 2. ICTs used by students with LDs to do academic work and recommendations of experts

\begin{tabular}{lll}
\hline ICT & Students with LDs & Experts \\
\hline Multipurpose ICTs & $86 \%$ & $71 \%$ \\
Office suite & $6 \%$ & $45 \%$ \\
${ }^{\mathrm{b}}$ Kurzweil & $3 \%$ & $19 \%$ \\
Wynn & $3 \%$ & $17 \%$ \\
Médialexie (French language multipurpose software) & $\mathrm{N} / \mathrm{A}$ & $5 \%$ \\
ClaroRead & & \\
Dictation: Speech-to-Text & $10 \%$ & $65 \%$ \\
Dictation software & $\mathrm{N} / \mathrm{A}$ & $5 \%$ \\
SpeakQ & & $47 \%$ \\
Grammar/Spelling & $65 \%$ & $29 \%$ \\
${ }^{\mathrm{a}}$ Antidote (French language grammar/spelling software) & $25 \%$ & $2 \%$ \\
${ }^{\mathrm{a}}$ WordQ & $58 \%$ & \\
Electronic dictionary & & $38 \%$ \\
Screen Reading: Text-to-Speech & $18 \%$ & $12 \%$ \\
Software that reads what is on the screen & $4 \%$ & $2 \%$ \\
ReadPlease & $30 \%$ & \\
MP3 to listen to books/texts & & $0 \%$ \\
Reading & $11 \%$ & $0 \%$ \\
E-book & $4 \%$ & \\
E-book reader (e.g., Kindle, Sony) & & \\
\hline
\end{tabular}


PDF (e.g., Adobe Acrobat Reader)

$74 \%$

$0 \%$

Scanning and optical character recognition (OCR)

${ }^{\mathrm{b}}$ Scanning and optical character recognition (OCR)

$\begin{array}{ll}27 \% & 9 \% \\ \text { N/A } & 9 \% \\ \text { N/A } & 3 \%\end{array}$

OpenBook

N/A

$3 \%$

Mind-Mapping /Concept Mapping

Inspiration/Concept mapping

$10 \%$

$41 \%$

Recording

Digital recorder

$16 \% \quad 16 \%$

Smartpen

$3 \%$

$3 \%$

Other

Laptop

$85 \%$

$36 \%$

${ }^{\mathrm{b}}$ Smartphone/cell phone/iPod, etc.

$69 \% \quad 10 \%$

${ }^{\mathrm{b}}$ Instant messaging (e.g., MSN, Skype)

$72 \%$

$0 \%$

Digital course materials

$\mathrm{N} / \mathrm{A}$

$5 \%$

Online courses/Notes

$\mathrm{N} / \mathrm{A}$

$5 \%$

Spark-Space

$\mathrm{N} / \mathrm{A}$

$5 \%$

Word highlighting feature

$\mathrm{N} / \mathrm{A}$

$3 \%$

Note. No significant difference between students from English and French colleges unless item is flagged with a superscript. N/A indicates that participants were not asked about this.

${ }^{a}$ French speaking students use significantly more often than English speaking students.

${ }^{\mathrm{b}}$ English speaking students use significantly more often than French speaking students.

\subsubsection{Where did Students Learn to Use ICTs?}

Results in Table 3 suggest that students with an LD from the English college were more likely than those from the French colleges to learn to use ICTs in high school or earlier. Students from the French colleges were more likely to learn to use these on their own or at the college.

Table 3. Where students learned to use their ICTs by language of college and LD status

\begin{tabular}{|c|c|c|c|c|c|c|c|c|}
\hline \multirow{3}{*}{ Response } & \multicolumn{4}{|c|}{ LD } & \multicolumn{4}{|c|}{ Non-LD } \\
\hline & \multicolumn{2}{|c|}{$\begin{array}{l}\text { English } \\
(\mathrm{n}=24)\end{array}$} & \multicolumn{2}{|c|}{$\begin{array}{l}\text { French } \\
(\mathrm{n}=29)\end{array}$} & \multicolumn{2}{|c|}{$\begin{array}{l}\text { English } \\
(\mathrm{n}=53)\end{array}$} & \multicolumn{2}{|c|}{$\begin{array}{c}\text { French } \\
(\mathrm{n}=52)\end{array}$} \\
\hline & $\mathrm{n}$ & $\%$ & $\mathrm{n}$ & $\%$ & $\mathrm{n}$ & $\%$ & $\mathrm{n}$ & $\%$ \\
\hline On My Own & 9 & $38 \%$ & 15 & $52 \%$ & 27 & $51 \%$ & 21 & $40 \%$ \\
\hline School (unspecified) & 8 & $33 \%$ & 7 & $24 \%$ & 15 & $28 \%$ & 21 & $40 \%$ \\
\hline Home & 7 & $29 \%$ & 4 & $14 \%$ & 15 & $28 \%$ & 18 & $35 \%$ \\
\hline High School & 6 & $25 \%$ & 2 & $7 \%$ & 9 & $17 \%$ & 11 & $21 \%$ \\
\hline College & 3 & $13 \%$ & 7 & $24 \%$ & 6 & $11 \%$ & 10 & $19 \%$ \\
\hline Family & 3 & $13 \%$ & 4 & $14 \%$ & 8 & $15 \%$ & 5 & $10 \%$ \\
\hline Friends & 2 & $8 \%$ & 2 & $7 \%$ & 9 & $17 \%$ & 7 & $13 \%$ \\
\hline Other & 2 & $8 \%$ & 4 & $14 \%$ & 2 & $4 \%$ & 5 & $10 \%$ \\
\hline Grade School & 2 & $8 \%$ & 0 & $0 \%$ & 3 & $6 \%$ & 1 & $2 \%$ \\
\hline
\end{tabular}


3.2 Comparing Views about ICTs: Students with an LD vs. Adequate and Very Poor Readers without an LD from French and English Colleges

Two-way analysis of variance (3 groups [LD, Non-LD Adequate, Non-LD Very Poor Reader)] x 2 Language [English, French]) shows that, overall, students from all three groups liked courses that used ICTs ( $M=4.68, \mathrm{SD}$ $=1.41$ on a scale where 6 indicates strong agreement and 1 indicates strong disagreement), and that they felt that ICTs helped them do their school work $(\mathrm{M}=4.89, \mathrm{SD}=1.32)$. There were no significant differences among the three groups or among students from English and French colleges.

Results based on the same 6-point scale also show that students were generally unlikely to miss classes when lecture notes were available online, although Very Poor Readers $(\mathrm{M}=3.90, \mathrm{SD}=1.51)$ were significantly, $\mathrm{F}(2,150)=3.83, \mathrm{p}=.024$, more likely to do so than Adequate Readers $(\mathrm{M}=4.38, \mathrm{SD}=1.05)$ or students with an $\mathrm{LD}(\mathrm{M}=4.42, \mathrm{SD}=1.09)$. Again, there was no significant difference between students from English and French colleges.

Although students generally felt they were reasonably well prepared to use ICTs at college $(\mathrm{M}=4.33, \mathrm{SD}=$ $1.63)$, the interaction between Group and Language was significant, $F(2,163)=3.25, p=.041$. Best seen in Figure 1, this indicates that compared to students from the English college $(\mathrm{M}=4.72, \mathrm{SD}=1.63)$, Very Poor Readers and students with LDs from the French colleges $(\mathrm{M}=3.59, \mathrm{SD}=1.71)$ were more likely to indicate that they were inadequately prepared.

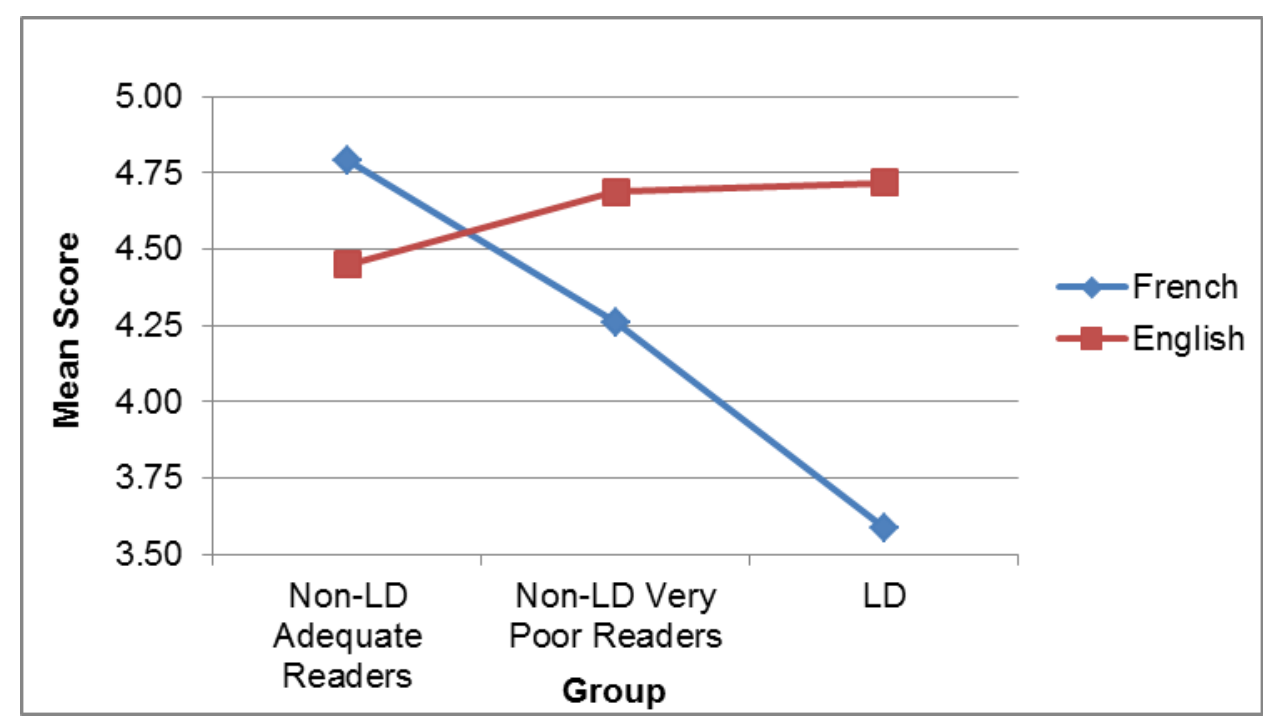

Figure 1. Group x Language interaction for the question, "When I started college, I was well prepared to use ICTs for my school work" ( 1 = strongly disagree, 6 = strongly agree $)$

Figure 2 shows that students with an LD were significantly, $\mathrm{F}(2,164)=3.22, \mathrm{p}=.043$, less likely to rate themselves as knowledgeable about ICTs than did Adequate Readers, while Very Poor Readers had scores between these two groups. This was true for both French and English students. 


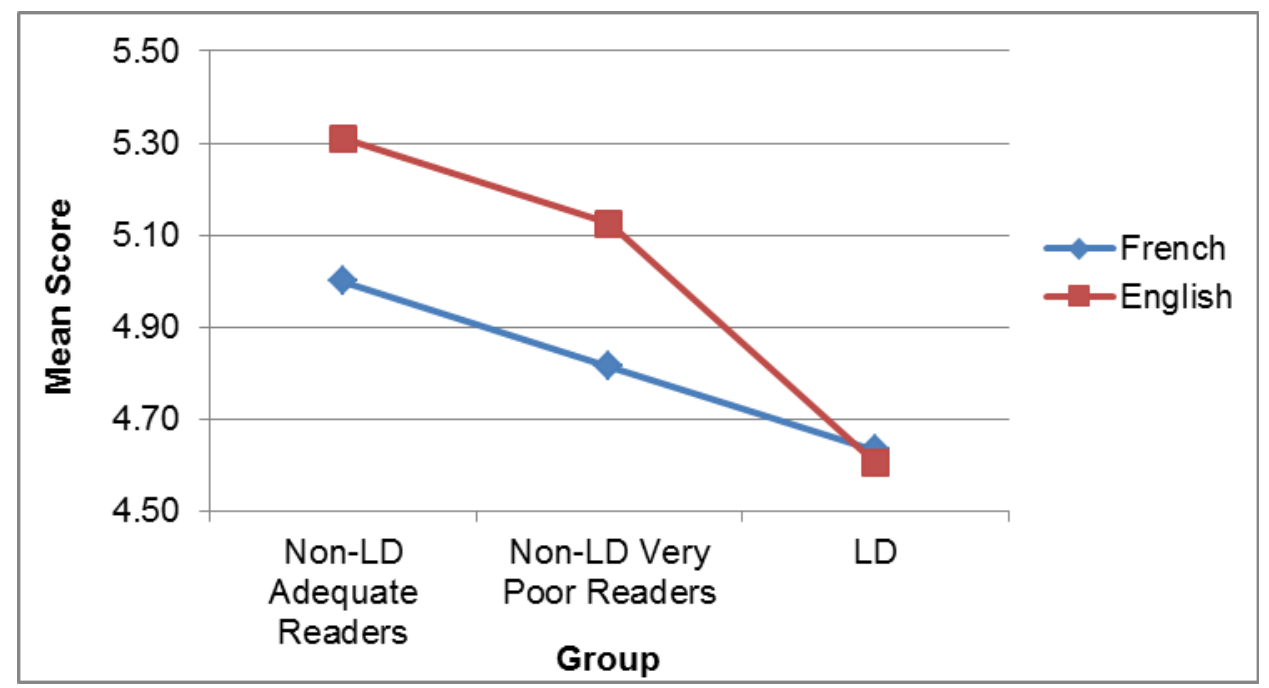

Figure 2. Findings for the question, "I am very knowledgeable in the use of ICTs"

$(1=$ strongly disagree, $6=$ strongly agree $)$

Figure 3 suggests that students from the French colleges were generally less comfortable with ICTs than those from the English college, and that students with an LD were less comfortable with ICTs than Very Poor Readers who, in turn, were less comfortable than Adequate Readers. These comparisons only approached significance $\mathrm{F}(1,164)=3.54, \mathrm{p}=.062$, and $\mathrm{F}(2,164)=2.90, \mathrm{p}=.058)$, respectively.

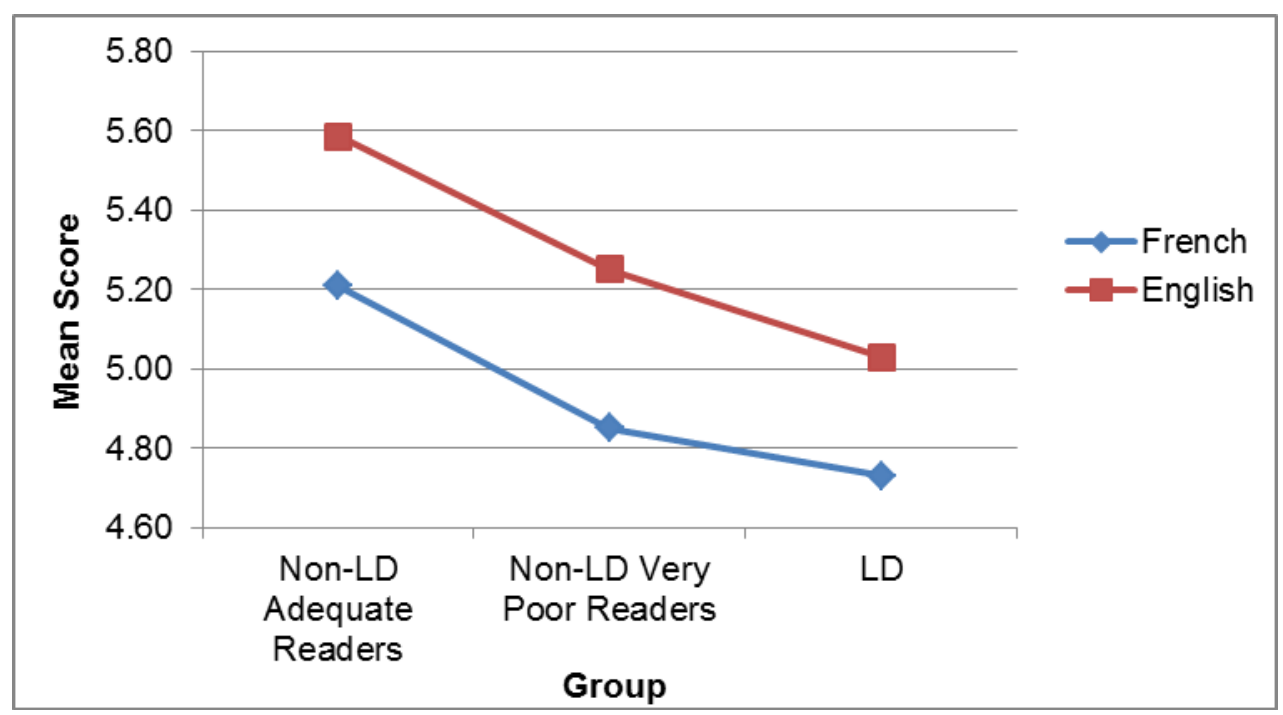

Figure 3. Findings for the question, "I am very comfortable using ICTs" $(1=$ strongly disagree, $6=$ strongly agree $)$ 
Figure 4 shows that students with an LD used significantly, $F(2,164)=8.64, \mathrm{p}=.000$, fewer different ICTs to do various aspects of their school work $(\mathrm{M}=3.27, \mathrm{SD}=1.91)$ than either Adequate $(\mathrm{M}=4.47, \mathrm{SD}=1.72)$ or $\mathrm{Very}$ Poor $(\mathrm{M}=4.49, \mathrm{SD}=1.87)$ Readers, who did not differ from each other. Students from French and English colleges did not differ significantly.

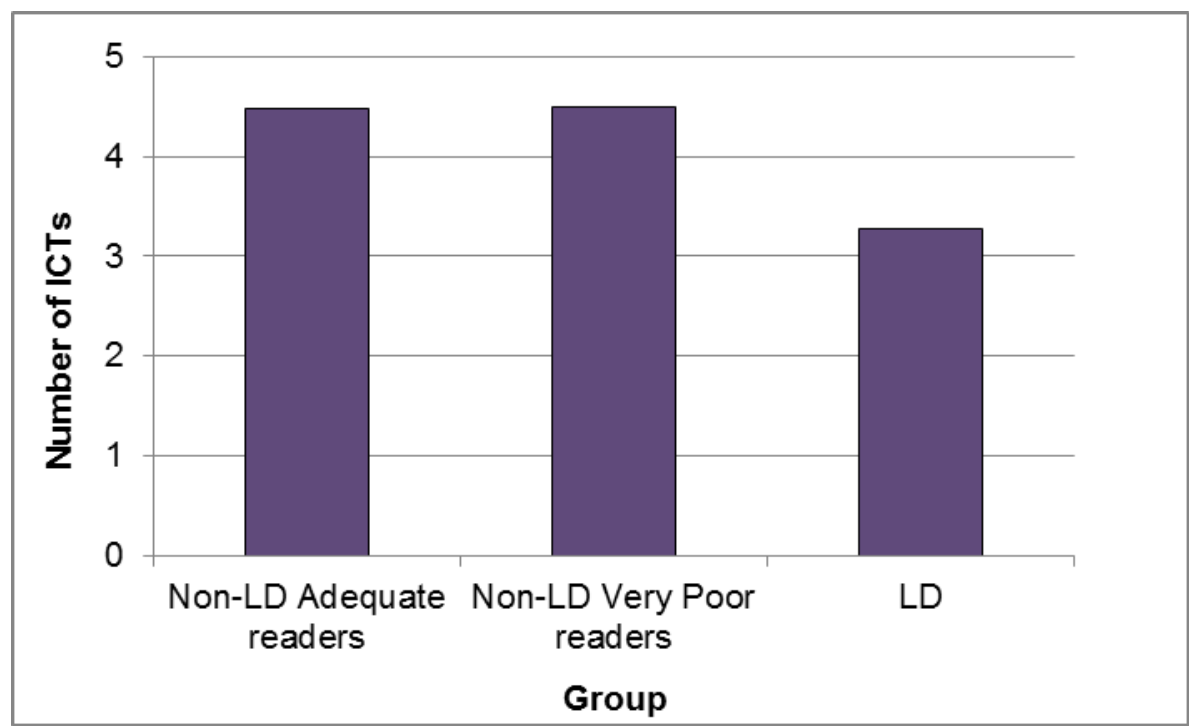

Figure 4. Group main effect for the total number of different ICTs used by Adequate Readers, Very Poor Readers and students with an LD to do various aspects of school work

For use of course websites (e.g., Moodle), the results indicate only a significant, $\mathrm{F}(2,167)=3.79, \mathrm{p}=.025$, interaction. Best seen in Figure 5, this shows that relative to students from the English college, students with an LD from French colleges were less likely to use course websites.

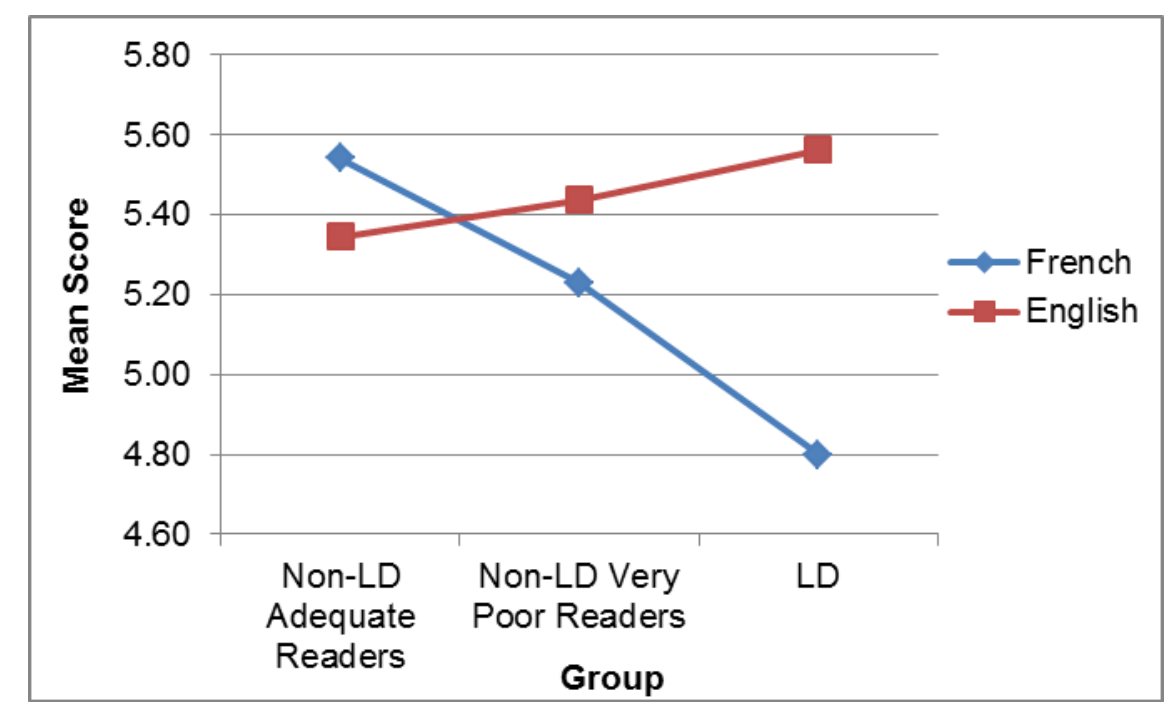

Figure 5. Group x Language interaction for the question, "I use course web sites regularly" ( 1 = strongly disagree, 6 = strongly agree).

\subsection{How Well Students' ICT Related Needs Are Met}

POSITIVES Scale (Fichten et al., 2010; Nguyen et al., in press) subscale results show that: ICTs available at the English college significantly better met the needs of students both with and without LDs than ICTs at French colleges, $\mathrm{F}(1,160)=6.72, \mathrm{p}=.010$; that professors' use of e-learning better met the needs of Adequate and Very Poor Readers without an LD than those of students with an $\mathrm{LD}, \mathrm{F}(2,162)=6.25, \mathrm{p}=.002$, and that there were 
no significant differences on ICTs used at home (see Table 4). Overall, the POSITIVES Scale Total score shows that needs of students in the English college were better met than those of students from the French colleges, $\mathrm{F}$ $(1,161)=5.44, \mathrm{p}=.021$.

Table 4. How well students' ICT related needs are being met: mean scores

\begin{tabular}{|c|c|c|c|c|c|}
\hline Group & & Language & $\begin{array}{l}\text { ICTs at School Meet } \\
\text { Student's Needs }\end{array}$ & $\begin{array}{l}\text { ICTs at Home Meet } \\
\text { Student's Needs }\end{array}$ & $\begin{array}{l}\text { E-learning ICTs } \\
\text { Meet Student's } \\
\text { Needs }\end{array}$ \\
\hline \multirow{2}{*}{$\begin{array}{l}\text { Non-LD } \\
\text { Readers }\end{array}$} & \multirow[t]{2}{*}{ Adequate } & English & 5.09 & 4.75 & 5.23 \\
\hline & & French & 4.87 & 5.06 & 5.21 \\
\hline \multirow{2}{*}{$\begin{array}{l}\text { Non-LD } \\
\text { Readers }\end{array}$} & \multirow[t]{2}{*}{ Very Poor } & English & 4.94 & 5.25 & 5.31 \\
\hline & & French & 4.62 & 4.71 & 5.15 \\
\hline \multirow[t]{2}{*}{ LD } & & English & 5.14 & 4.76 & 4.93 \\
\hline & & French & 4.74 & 4.58 & 4.66 \\
\hline
\end{tabular}

\section{Discussion}

\subsection{Sample Characteristics}

It is important to note that the samples in this investigation are not representative of students in Québec's colleges, since we purposely targeted very poor readers and students with an LD. Representative sampling (Fichten et al., in press) shows that $4.0 \%$ of English and $4.4 \%$ of French college students self-reported a "learning disability such as dyslexia," and that only $59 \%$ of them had registered to receive disability related services from their college.

There are numerous reasons for failing to register for disability related services. Lightner et al.'s (2012) study shows that the following reasons, in rank order, were indicated by university students who had received LD related accommodations in high school, but who had not registered in the first semester of their university studies: lack of time; lack of knowledge about procedures, their own disability, and the range of services offered; identity; things going well; the cost and/or hassle of needed testing; the perception that they would be "cheating"; shame; and scheduling conflicts.

Another interesting finding concerns the substantial numbers of very poor readers whose native language is either English or French and who do not report an LD. Although it is well known that these students exist in colleges and universities (e.g., Parrila et al., 2007; Mimouni, 2006; Mimouni \& King, 2007), little is known about the ICTs that could benefit them.

It is also noteworthy that approximately $1 / 3$ of students who self-reported an LD fell into the adequate reader category. This may be due to a variety of factors, including the varied nature of learning disabilities and to the phenomenon of "compensated dyslexics" who, by the time they enter college, have learned effective reading strategies (e.g., McGonnell, Parrila, \& Deacon, 2007). The finding that $1 / 3$ of students with LDs are adequate readers does, however, make it clear that students with an LD can have difficulties in academic areas other than those dealing with reading and dyslexia. Therefore, it is important to make students aware of ICTs that could help them not only with reading, but also with writing, spelling, organizing, and remembering.

\subsection{Differences in ICT Use}

Contrary to what many might believe, ICT profiles of students did not vary based on gender or college program. Overall, the results show that students with an LD, whether enrolled in a French or an English college, used fewer different ICTs to do their school work than either adequate or very poor readers. This was surprising, since we expected students with an LD to use all of the usual general-use ICTs, such as Microsoft Office, along with at least some specialized ICTs, such as WordQ or Kurzweil.

Comparison of the views of the experts and the realities of students with LDs suggest important discrepancies. First, students with an LD do not use many ICTs that experts believe could benefit them. Conversely, students 
reported using smartphones/cell phones/iPods, MP3 players, and instant messaging as productivity tools; these are general-use ICTs that the experts did not mention. Clearly, students and experts need to share their perspectives about ICTs that could be useful.

The results also showed differences in ICT use between students from English and French colleges. First, students from the English college, whether they had an LD or not, reported using a larger variety of ICTs than students from the French colleges. Although students with an LD from the French colleges were more likely to use Antidote (French grammar and spelling software) and WordQ (bilingual word prediction program), students from the English college were more likely to use Macintosh computers, smartphones/cell phones/iPods, instant messaging, Kurzweil (bilingual multipurpose software), as well as scanning and optical character recognition (renders paper based materials into e-text).

There were also systematic linguistic differences in how students with an LD learned to use ICTs. Students from the English college were more likely to learn these in high school or earlier, while students from the French colleges were more likely to do so on their own or at college.

Whether they were enrolled in French or English colleges, consistent with others' findings (e.g., Parker \& Banerjee, 2007), students with an LD were less likely to rate themselves as knowledgeable about ICTs than did adequate readers, while very poor readers had scores between these two groups. Adequate readers from both French and English colleges felt reasonably well prepared to use ICTs at college. When it came to very poor readers and students with an LD, those enrolled in French colleges were more likely to indicate that they were inadequately prepared. Students in all three groups who were enrolled in the French colleges felt less comfortable using ICTs than their peers from the English college, with students with LDs being least comfortable, regardless of language. Whether linguistic differences reflect instructional trends or attitudes toward ICTs in high schools or differences in training opportunities in the colleges, it is important to stress that good learning opportunities need to be available to students once they enter college. This is vital since reading and writing loads tend to be heavier and, therefore, some students first experience academic difficulties only at the college level (Harrison, Larochette, \& Nichols, 2007).

Students from all three groups reported liking courses that used ICTs. They also felt that ICTs helped them do their school work. Moreover, students were generally unlikely to miss classes when lecture notes were available online, although very poor readers who did not have an LD were more likely to skip classes when notes were available than students from the other two groups. Relative to students with an LD from the English college, students with an LD from the French colleges were less likely to use course websites.

Findings using the POSITIVES Scale (Fichten et al., 2010; Nguyen et al., in press) show that students felt that ICTs at school at the English college significantly better met their needs, whether they had an LD or not, than students at the French colleges. There was no linguistic difference on how well professors' use of e-learning met students' needs, although needs of students with LDs were the least well met. When it came to ICTs for home use, there were no significant differences.

Overall, the results show some important differences between experiences of students from English and French colleges. The results also point to differences between students with an LD and both adequate and very poor readers. One noteworthy finding is that students with LDs used fewer and less varied ICTs than their peers without an LD. While others, too, have reported that many students with an LD do not use specialized ICTs, studies also show that those students who do use specialized ICTs are, on the whole, quite satisfied with the results (e.g., Brown, 2007; Fidler, 2002, cited in Draffan et al., 2007)

\subsection{Limitations}

It should be noted that there are several limitations of the present investigation which can affect the generalizability of the results. First, there was only one English college sampled and only participants from a single Canadian province, Quebec, were studied. Second, poor readers and students with learning disabilities were oversampled. And third, we purposely excluded second language learners, whose ICT use profiles may differ from those of primarily English and French speakers.

\subsection{Recommendations}

So what can be done to inform students with LDs about ICTs that could assist them in their studies? First, it is important to understand the reasons why students with an LD do not use potentially helpful ICTs. Some students may not wish to be singled out as different - a disabled student - or to be seen as "cheating" by using ICTs when others are not permitted to do so. Some are unaware about the existence of needed ICTs. There are students who do not know where to acquire these. Students are often unable to pay for expensive ICTs. Finally, some students 
simply do not know how to use these. An additional complication is that many students are unaware that they have an LD (Harrison, Larochette, \& Nichols, 2007), and believe, instead, along with their parents and teachers, that they are simply poor students. Thus, it simply does not occur to them that ICTs could help. Coupled with the substantial numbers of students with an LD in our colleges, many of whom are not registered for disability related services (Fichten et al., in press), institution-wide initiatives are needed to publicize software and hardware solutions that could help these students, as well as very poor readers and second (or third) language learners, succeed in their studies.

One concern repeated throughout all of our studies has been the high cost of specialized ICTs. In response to this, we have compiled and continually update a list of free and/or inexpensive ICT alternatives - Windows and Macintosh based as well as mobile apps - that might be useful. These can be found, in English and French, in the "Downloads" section of the Adaptech Research Network/Réseau de Recherche Adaptech web site $<$ http://www.adaptech.org $>$. Some of these ICTs are long-running demos, while others are fully functional. We are not suggesting that these replace the higher end products currently on the market. However, as a short-term solution, or to try different specialized ICTs, we think they are a good place to start. We have also produced a series of short training videoclips to demonstrate how to use some of these. Videoclips can be found, in French and English, on our YouTube channel <http://www.YouTube.com/AdaptechResearch>.

To assist all students with reading and writing concerns, we recommend that colleges hold ICT technology fair days where they demonstrate various forms of general use and specialized ICTs to the student body, including academic use of smartphones, MP3s, tablets, cloud-based software, and instant messaging. Ongoing support and brief training workshops, offered at various times during the semester, could also benefit students along with YouTube training videoclips.

While it would be useful to present empirical data which demonstrate that using ICTs improves the academic performance of students with LDs, such studies are scarce. Hewlett, Burnett, and Owen (2006) highlighted some of the most glaring difficulties. These include: participants vary in age and reading and/or writing abilities, methodologies lack consistency, and results are mixed. In addition, studies employ very small samples, participants vary in experience with the specialized ICTs in question, reading and writing tasks employed often fail to resemble college level work, and training on the ICTs can involve teaching reading/writing strategies as well, thereby confounding the results. Therefore, such studies are very difficult to execute. Of course, different investigators use different ICTs; in several instances these are multipurpose products designed especially for the study. Indeed, Li and Hamel (2003), who undertook a systematic review of ICTs and students with LDs for the period 1990 to 2000, found only four empirical studies of effectiveness. Our own literature review, conducted in 2012, also revealed a shocking paucity of empirical studies and no conclusive findings.

Based on the literature, we cannot state, definitively, that ICTs will improve the academic success of students with LDs. Of course, we can say even less about ICTs and very poor readers without LDs or about students who are not proficient in the language of instruction. Nevertheless, it is likely that ICTs will assist these students, at least to the same extent as ICTs assist adequate readers.

\section{Acknowledgements}

This project was funded by the Ministère de l'Éducation, du Loisir et du Sport du Québec (MELS) in collaboration with the Fonds de recherche du Québec - Société et culture (FRQSC) [grant number 2009-PE-130944] in the Actions concertées program. We also received funding from the Social Sciences and Humanities Research Council of Canada.

\section{References}

Adaptech Research Network/Réseau de Recherche Adaptech. (2012). October 2012 - Updated database of free \& inexpensive computer technologies/Octobre 2012 - Mise à jour de la section téléchargement. Retrieved from http://www.adaptech.org

AQICESH. (2011). Beaucoup restent à faire pour les étudiants en situation de handicap. Bulletin AQICESH, 4, 1.

Brown, S. A. (2007). Student perceptions of the efficacy of learning disability support services (Ed. D. Dissertation). University of California, Los Angeles. (UMI Number 3299588).

Chouinard, L., \& Déry, D. (2008, May). ÉTAPE (Élèves en troubles d'apprentissage: projet expérimental). Presentation at the Journée d'échange du 26 mars 2008 sur l'organisation des services offerts aux étudiants présentant des problèmes graves de santé mentale et des troubles d'apprentissage, Charlesbourg, Quebec.

Draffan, E. A., Evans, D. G., \& Blenkhorn, P. (2007). Use of assistive technology by students with dyslexia in 
post-secondary education. Disability and Rehabilitation: Assistive Technology, 2(2), 105-116. http://dx.doi.org/10.1080/17483100601178492

Fichten, C. S., Asuncion, J. V., Nguyen, M. N., Budd, J., \& Amsel, R. (2010). The POSITIVES Scale: Development and validation of a measure of how well the ICT needs of students with disabilities are met. Journal of Postsecondary Education and Disability, 23(2), 137-154.

Fichten, C. S., Jorgensen, S., Havel, A., Barile, M., with the collaboration of Landry, M. E., Fiset, D., Juhel, J. C., Tétreault, S., Ferraro, V., Chwojka, C., Nguyen, M. N., Alapin, I., Arcuri, R., Huard, G., \& Amsel, R. (2006). College students with disabilities: Their future and success - Final report presented to FQRSC. Montreal: Adaptech Research Network, Dawson College. (ERIC Education Resources Information No. ED 491585).

Fichten, C. S., King, L., Nguyen, M. N., Barile, M., Havel, A., Chauvin, A., Budd, J., Mimouni, Z., Raymond, O., \& Juhel, J-C. (2012). Utiliser les technologies de l'information et de la communication afin d'améliorer la réussite collégiale des étudiants ayant des troubles d'apprentissage. Pédagogie Collégiale, 25(4), 32-37.

Fichten, C. S., Nguyen, M. N., King, L., Havel, A., Mimouni, Z., Barile, M., Budd, J., Jorgensen, S., Chauvin, A., \& Gutberg, J. (in press). How well do they read? Brief English and French screening tools for college students. International Journal of Special Education.

Gagné, Y., \& Tremblay, D. (2011). Statistiques concernant les étudiants en situation de handicap dans les universités québécoises : 2010-2011. Montreal: AQICESH.

Harrison, A. G., Larochette, A-C., \& Nichols, E. (2007). Students with learning disabilities in postsecondary education: Selected initial characteristics. Exceptionality Education Canada, 17(2), 135-154.

Hewlett, M. G., Burnett, A. N., \& Owen, W. J. (2006). An investigation into the benefits of text-to-speech software for postsecondary students with learning disabilities. Communiqué, 7(1), 8-12.

IREP. (2000). Test de lecture : épreuve de compréhension [Reading Test]. Ste-Agathe-des-Monts: IREP.

King, L., Mimouni, Z., \& Courtemanche, C. (2006). The persistence of reading deficits among college-level students. Paper Presented at the American Speech-Language-Hearing Association, Miami, Florida.

Lavallée, C., Raymond, O., \& Savard, H. (2011). L'accueil des étudiants ayant un trouble d'apprentissage au collégial. Rendez-vous AQETA, 25(2), 22-23.

Learning Disabilities Association of Canada. (undated). Welcome to learning disabilities association of Canada! Retrieved from http://www.ldac-acta.ca/

Learning Disabilities Association of Quebec. (undated). Association québécoise des troubles d'apprentissage AQETA - Section Outaouais. Retrieved from http://www.aqetaoutaouais.qc.ca/PDF/PDF/E/E12ang.pdf

Li, H., \& Hamel, C. M. (2003). Writing issues in college students with learning disabilities: A synthesis of the literature from 1990 to 2000. Learning Disability Quarterly, 26(1), 29-46.

Lightner, K. L., Kipps-Vaughan, D., Schulte, T., Trice, A. D., \& University, J. M. (2012). Reasons university students with a learning disability wait to seek disability services. Journal of Postsecondary Education and Disability, 25(2), 145-159.

McGonnell, M., Parrila, R., \& Deacon, S. H. (2007). The recruitment and description of university students who self-report difficulty acquiring early reading skills. Exceptionality Education Canada, 17(2), 155-174.

Mimouni, Z., \& King, L. (2007). Troubles de lecture au collégial: Deux mesures de soutien. Rapport de recherche. Final report presented to the Programme d'Aide à la Recherche sur l'Enseignement et l'Apprentissage (PAREA). Collège Montmorency: Montréal. Retrieved from http://www.cdc.qc.ca/parea/786681_king_mimouni_troubles_lecture_alaurendeau_montmorency_PAREA_ 2007.pdf

Mimouni, Z. (2006). La dyslexie développementale au collégial: Un premier profil. Correspondance, 11(3).

Nguyen, M. N., Fichten, C. S., \& Budd, J. (in press). Le développement de l'échelle POSITIVES : Satisfaction des étudiants en situation de handicap concernant les technologies de l'information et de la communication. Revue des sciences de l'éducation.

Parker, D. R., \& Banerjee, M. (2007). Leveling the digital playing field: Assessing the learning technology needs of college-bound students with LD and/or ADHD. Assessment for Effective Intervention, 33(1), 5-14. http://dx.doi.org/10.1177/15345084070330010201

Parrila, R., Georgiou, G., \& Corkett, J. (2007). University students with a significant history of reading 
difficulties: What is and is not compensated? Exceptionality Education Canada, 17(2), 195-220.

Rousseau, N. (2010). Troubles d'apprentissage et technologies d'aide: L'accès à une vie scolaire riche et stimulante. Quebec: Centre de transfert pour la réussite éducative du Québec.

Tremblay, M., Maliba, R., Deslières, C., Bédard M., \& Lefebvre, J. (2011). L'utilisation des aides technologiques au cégep : une réalité bien ancrée pour les étudiants ayant un trouble d'apprentissage. Rendez-vous AQETA, 25(2), 24-25.

Walcot-Gayda, E. (2004). Understanding learning disability? Ottawa: Learning Disabilities Association of Canada. Retrieved from http://www.ldhope.com/understanding-LD.htm 